\title{
STUDI KANDUNGAN LOGAM BERAT TIMBAL (PB) PADA BUAH YANG DIJUAL DIPINGGIR JALAN \\ Study Of The Heavy Metal Content Of Lead (Pb) Infruit Sold On The Roadside Syamsuddin $\mathbf{S}^{1}$, Irnawati $^{2}$ \\ 1,2Jurusan Kesehatan Lingkungan Politeknik Kesehatan Kemenkes Makassar \\ *)syam.kesling@gmail.com
}

\begin{abstract}
Lead or known as $\mathrm{Pb}$ metal as a motor vehicle exhaust gas can endanger the health and damage the environment. PB that is inhaled by humans every day will be absorbed, stored, and then stored in the blood. The purpose of this study is to determine the lead content of fruit sold along the roadside. This type of research is research that is a literature study. The data source used in this study is secondary data from research journals published on the internet related to the content of lead-heavy metals $(\mathrm{Pb})$ in fruit sold along the road. The results of this study contained 1 study which showed that the lead content in the fruit did not meet the requirements based on the Regulation of the Food and Drug Administration No.5 of 2018 concerning the Maximum Limit of Heavy Metal Contamination in Processed Food. The maximum standard of heavy metal contamination on fruit is $0.20 \mathrm{mg} / \mathrm{kg}$. Based on the results it can be concluded that the length of time of display, the number of vehicles passing by, and weather factors affect the lead level in fruit sold along the roadside

Keywords: Lead (Pb), fruit
\end{abstract}

\section{ABSTRAK}

Timbal atau dikenal dengan logam $\mathrm{Pb}$ sebagai gas buangan kendaraan bermotor dapat membahayakan kesehatan dan merusak lingkungan. $\mathrm{Pb}$ yang terhirup oleh manusia setiap hari akan diserap, disimpan dan kemudian ditampung dalam darah. Adapun tujuan penelitian ini yaitu untuk mengetahui kandungan timbal pada buah yang dijual dipinggir jalan.Jenis penelitian yang digunakan adalah penelitian yang bersifat studi kepustakaan.Sumber data yang digunakan dalam penelitian ini berupa data sekunder dari jurnal hasil penelitian yang terpublikasikan di internet terkait dengan kandungan logam berat timbal $(\mathrm{Pb})$ pada buah yang dijual dipinggir jalan. Hasil dari penelitian ini terdapat 1 penelitian yang menunjukkan kandungan timbal pada buah yang tidak memenuhi syarat berdasarkan Peraturan Badan Pengawasan Obat dan Makanan No.5 Tahun 2018 Tentang Batas Maksimum Cemaran Logam Berat Dalam Pangan Olahan. Standar maksimum cemaran logam berat pada buah adalah 0,20 mg/kg.Dapat disimpulkan bahwa lamanya waktu pemajangan, jumlah kendaraan yang lewat dan faktor cuaca mempengaruhi kadar timbal pada buah yang dijual dipinggir jalan.

Kata kunci: Timbal $(\mathrm{Pb})$, buah.

\section{PENDAHULUAN}

Timbal atau dikenal dengan logam $\mathrm{Pb}$ dalam susunan unsur merupakan logam berat yang terdapat secara alami di dalam kerak bumi dan tersebar ke alam dalam jumlah kecil melalui proses alami. Timbal $(\mathrm{Pb})$ pada awalnya pada awalnya adalah lagam berat yang secara alami terdapat dalam kerak bumi. Namun, juga bias berasal dari dari kegiatam manusia bahkan mampu mencapai jumlah 300 kali lebih banyak dibandingkan $\mathrm{Pb}$ alami (Widowati, 2009).

Timbal $(\mathrm{Pb})$ kini dianggap sebagai ancaman serius dan mendapat perhatian utama dari segi kesehatan karena dampaknya pada manusia akibat keracunan makanan atau udara yang terkontaminasi memiliki sifat racun berbahaya.Anak-anak sangat rentan terhadap efek racun timbal dan dapat menderita efek yang merugikan kesehatan dan sifatnya permanen, khususnya yang mempengaruhi perkembangan otak dan sistem saraf.Timbal juga menyebabkan kerusakan jangka panjang pada orang dewasa, termasuk peningkatan risiko tekanan darah tinggi dan kerusakan ginjal.Pada ibu hamil dapat menyebabkan keguguran, lahir mati, lahir premature dan berat badan lahir rendah.
Institute For Health and Evaluation (IHME) pemperkirakan bahwa pada tahun 2017, paparan timbal mengakibatkan 1,06 juta kematian dan 24,4 juta mengalami kehilangan hidup sehat (kecacatan) di seluruh dunia karena efek jangka panjang pada kesehatan terutama di Negara berpenghasilan rendah dan menengah. IHME juga memperkirakan bahwa pada tahun 2016, papran timbal berkontribusi $63,2 \%$ penurunan kecedasan, 10,3\% mengalami tekanan darah tinggi, $5,6 \%$ mengalami gangguan pada jantung, dan $6,3 \%$ mengalami stroke.

Emisi timbal di udara dapat berupa gas atau partikel sebagai hasil samping pembakaran yang kurang sempurna dalam mesin kendaraan bermotor. Semakin kurang sempurna proses pembakaran dalam mesin kendaraan bermotor, maka semakin banayk jumlah timbal yang dihasilkan. Penggunaan timbal dalam bahan bakar adalah untuk meningkatkan oktan bahan bakar.Tetra Ethyl Lead (TEL), selain meningkatkan oktan juga dipercaya berfungsi sebagai pelumas dudukan katup mobil, sehingga katup tetap terjaga dari keausan, lebih awet, dan tahan lama. (Adhani, 2017)

Timbal $(\mathrm{Pb})$ dapat masuk ke tubuh melalui inhalasi, makanan dan minuman serta 
absorbs melalui kulit. Timbal $(\mathrm{Pb})$ sebagai gas buangan kendaraan bermotor dapat membahayakan kesehatan dan merusak lingkungan. $\mathrm{Pb}$ yang terhirup oleh manusia setiap hari akan diserap, disimpan dan kemudian ditampung dalam darah. (Ruhban, 2017).Rata-rata $10-30 \% \mathrm{~Pb}$ yang terhirup diabsorpsi melalui paru-paru, dan sekitar 5$10 \%$ dari $\mathrm{Pb}$ yang tertelan diabsorpsi melalui saluran pencernaan.

Logam timbal $(\mathrm{Pb})$ dapat masuk ke tubuh melalui makanan jajanan yang dijual di pinggir jalan dalam keadaan terbuka. Hal ini akan lebih berbahaya lagi apabila makanan tersebut didagangkan dalam waktu yang lama. Timbal $(\mathrm{Pb})$ yang terdapat dalam asapasap kendaraan bermotor merupakan salah satu sumber pencemaran terhadap buahbuahan yang dijual di pinggir jalan.

Terdapat beberapa penelitian di Indonesia terkait pencemaran timbal $(\mathrm{Pb})$ pada buah, salah satunya adalah di kota Malang dengan hasil pengukuran kadar logam timbal pada buah apel yang dianalisis adalah sebesar $9,305 \mathrm{mg} / \mathrm{kg}$ pada sampel buah manalagi dan $6,821 \mathrm{mg} / \mathrm{kg}$ pada sampel buah apel granny smith. Selain itu peneitian lainnya yaitu Identifikasi Kandungan Logam Timbal (Pb) Pada Buah Nangka (Artocarpus

\section{METODE PENELITIAN}

\section{Jenis penelitian}

Adapun jenis penelitian ini adalah penelitian studi kepustakaan.Sumber data yang digunakan dalam penelitian ini berupa data sekunder dari jurnal hasil penelitian yang terpublikasikan di internet terkait dengan kandungan logam berat timbal $(\mathrm{Pb})$ pada buah yang dijual dipinggir jalan.

\section{Waktu penelitian}

Waktu penelitian dilaksanakan pada bulan Mare hingga Juni 2021

\section{Pengumpulan data}

Pengumpulan data dalam penelitian ini dilakukan dengan mengumpulkan jurnal-jurnal yang berkaitan dengan kandungan logam berat timbal $(\mathrm{Pb})$ pada buah yang dijual dipinggir jalan.Kemudian dipilih, disajikan dan dianalisis.
Heterophyllus) Di Media Jalan Kota Bandar Lampung.rataan kandungan timbal sebesar $1,05 \mathrm{mg} / \mathrm{kg}$. Kandungan timbal buah nangka pada median jalan Kota Bandar Lampung dipengaruhi oleh faktor, usia pohon, topografi jalan bentuk tikungan, geometri jalan bentuk tanjakan, dan geometri jalan bentuk turunan.Nilai itu tentu saja melewati nilai ambang batas pada buah apel.

Kadar timbal $(\mathrm{Pb})$ pada buah-buahan dikatakan memenuhi syarat apabila tidak melampaui batas maksimal (ppm atau $\mathrm{mg} / \mathrm{kg}$ ) untuk jenis buah-buahan berdasarkan Peraturan Badan Pengawasan Obat dan Makanan No.5 Tahun 2018 Tentang Batas Maksimum Cemaran Logam Berat Dalam Pangan Olahan. Standar maksimum cemaran logam berat pada buah adalah $0,20 \mathrm{mg} / \mathrm{kg}$ (BPOM: 2018).

Adanya resiko tercemarnya buahbuahan oleh logam berat terutama logam timbal yang dapat membahayakan kesehatan konsumen, dan masih terbatasnya pustaka mengenai kandungan logam berat timbal pada buah.Oleh karena itu, peneliti tertarik melakukan penelitian kepustakaan terkait dengan kadungan logam berat timbal $(\mathrm{Pb})$ pada buah.

\section{Pengolahan data}

Pengolahan data yang digunakan dalam penelitian studi kepustakaan ini yaitu dengan analisis isi (content analysis). kemudian dinarasikan secara deskriptif dengan membandingkan hasil penelitian dengan standar cemaran logam berat pada pangan berdasarkan BPOM No.5 tahun 2018 batas maksimum cemaran logam berat pada pangan.

\section{Penyajian data}

Penyajian data yang digunakan dalam penelitian ini adalah data disajikan dalam bentuk tabel.

\section{HASIL PENELITIAN}

Penelitian ini dilakukan dengan menganalisis isi dari 4 jurnal terkait kandungan timbal pada buah yang dijual dipinggir jalan. 
Jurnal Sulolipu : Media Komunikasi Sivitas Akademika dan Masyarakat

Vol. 21 No.12021

e-issn: 2622-6960, p-issn : 0854-624X

Tabel 1

Analisis cemaran logam timbal $(\mathrm{pb})$ pada buah pir yang dijual dipinggir jalan simpang empat lampu merah jalan soekarno hatta kota Pekanbaru

\begin{tabular}{|c|c|c|}
\hline Judul & Penelitian, tahun & 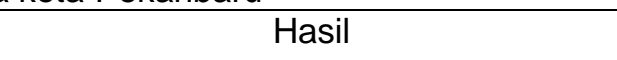 \\
\hline $\begin{array}{l}\text { Analisis cemaran logam } \\
\text { timbal (pb) pada buah pir } \\
\text { yang dijual dipinggir jalan } \\
\text { simpang empat lampu } \\
\text { merah jalan soekarno } \\
\text { hatta kota pekanbaru }\end{array}$ & $\begin{array}{lrr}\text { Lidya } & \text { Novita, } & \text { Esthy } \\
\text { Rahman } & \text { Asih,Aisyah } \\
2017 . & \end{array}$ & $\begin{array}{l}\text { Cemaran logam } \mathrm{Pb} \text { pada buah pir } \\
\text { yang telah dipajang pada berbagai } \\
\text { variasi waktu pajang. Sampel } \\
\text { pemajangan } 0 \text { hari tidak di cuci } \\
\text { sebesar } 2,1 \mathrm{mg} / \mathrm{kg} \text {, pada perlakuan } \\
\text { buah setelah dicuci tanpasabun, dicuci } \\
\text { dengan sabun dan dikupas kulitnya } \\
\text { yaitu sebesar } 0,7 \mathrm{mg} / \mathrm{kg} \text {, } 0,6 \mathrm{mg} / \mathrm{kg} \\
\text { dan } 0,5 \mathrm{mg} / \mathrm{kg} \text {. Sampel pemajangan } 6 \\
\text { hari pada perlakuan tidak dicuci } \\
\text { sebesar } 7,9 \mathrm{mg} / \mathrm{kg} \text {, dicuci tanpa sabun } \\
5,9 \mathrm{mg} / \mathrm{kg} \text {, dicuci dengan sabun } 4,4 \\
\mathrm{mg} / \mathrm{kg} \text {, dan dukupas } \mathrm{kulitnya} \text { sebesar } \\
2,7 \text { mg/kg. Dan pada sampel } \\
\text { pemajangan } 12 \text { hari tanpa dicuci } 18,5 \\
\mathrm{mg} / \mathrm{kg} \text {, dicuci tanpa sabun } 15,7 \mathrm{mg} / \mathrm{kg} \text {, } \\
\text { dicuci dengan sabun } 9,6 \mathrm{mg} / \mathrm{kg} \text {, dan di } \\
\mathrm{kupas} \text { kulitnya } 8,7 \mathrm{mg} / \mathrm{kg} \text {. }\end{array}$ \\
\hline
\end{tabular}

Table 2

Pengaruh waktu pemaparan terhadap kadar timbal dalam buah papaya (Carica papaya.L) yang dijual di beberapa pinggir

\begin{tabular}{|c|c|c|}
\hline Judul & Penelitian, tahun & Hasil \\
\hline $\begin{array}{l}\text { Pengaruh } \\
\text { pemaparan terhadap } \\
\text { kadar timbal dalam buah } \\
\text { papaya (Carica papaya.L) } \\
\text { yang dijual di beberapa } \\
\text { pinggir jalan di } \\
\text { Yogyakarta. }\end{array}$ & Vivi Elvira, 2011 & $\begin{array}{l}\text { Kadar timbal papaya kontrol } 0,15187 \\
\mathrm{mg} / \mathrm{kg} \text {. kadar timbal pada pedagang I } \\
\text { hari ke-4 yaitu } 0,15267 \mathrm{mg} / \mathrm{kg} \text { dan } \\
\text { pada hari ke-8 yaitu } 0,15650 \mathrm{mg} / \mathrm{kg} \text {. } \\
\text { kadar timbal pada pedagang II hari ke- } \\
4 \text { yaitu } 0,15440 \mathrm{mg} / \mathrm{kg} \text {, dan pada hari } \\
\text { ke-8 yaitu } 0,14972 \mathrm{mg} / \mathrm{kg} \text {. kadar timbal } \\
\text { pada pedagang III pada hari ke-4 yaitu } \\
0,15645 \mathrm{mg} / \mathrm{kg} \text { dan pada hari ke-8 } \\
\text { yaitu } 0,15908 \mathrm{mg} / \mathrm{kg} \text {. }\end{array}$ \\
\hline
\end{tabular}


Jurnal Sulolipu : Media Komunikasi Sivitas Akademika dan Masyarakat

Vol. 21 No. 12021

e-issn: 2622-6960, p-issn : 0854-624X

Table 3

Analisis kandungan kandungan timbal pada buah apel (pyrus malu.L) yang dipajangnkan dipinggir jalan kota Palu menggunakan metode spekterofotomerti serapan atom.

\begin{tabular}{|c|c|c|}
\hline Judul & Penelitian, tahun & Hasil \\
\hline $\begin{array}{l}\text { Analisis kandungan kandungan } \\
\text { timbal pada buah apel (pyrus } \\
\text { malu.L) yang dipajangnkan } \\
\text { dipinggir jalan kota Palu } \\
\text { menggunakan } \\
\text { spekterofotomerti serapan atom. }\end{array}$ & $\begin{array}{l}\text { Musafira, } \\
\text { sikanna, } \\
2015 .\end{array}$ & $\begin{array}{l}\text { Kandungan timbal pada sampel } \\
\text { buah yang dipajangkan di jalan } \\
\text { Sisingamangaraja pada buah apel } \\
0 \text { hari (Kontrol) yaitu } 0,110 \text { ppm, } \\
\text { hari ke-3 yaitu } 0,168 \mathrm{ppm} \text {, hari ke- } \\
6 \text { yaitu } 0,145 \mathrm{ppm} \text {, hari ke-12 yaitu } \\
187 \text { ppm. Pada sampel buah yang } \\
\text { dipajangkan di jalan Undata Palu, } \\
\text { kadar timbal pada buah hari } 0 \\
\text { (kontrol) sebesar } 0,077 \mathrm{ppm} \text {, pada } \\
\text { hari ke-3 yaitu } 0,162 \mathrm{ppm} \text {, hari ke- } \\
6 \text { sebesar } 0,152 \mathrm{ppm} \text { dan pada } \\
\text { hari ke-12 sebesar } 0,174 \mathrm{ppm} \text {. }\end{array}$ \\
\hline
\end{tabular}

Table 4

Perbandingan Kadar Timbal (Pb) pada Buah Jeruk yang Terpapar dengan yang Tidak Terpapar Polusi Kendaraan di Kota Cirebon

\begin{tabular}{|c|c|c|}
\hline Judul & Penelitian, tahun & Hasil \\
\hline $\begin{array}{l}\text { Perbandingan Kadar Timbal } \\
\text { (Pb) pada Buah Jeruk yang } \\
\text { Terpapar dengan yang Tidak } \\
\text { Terpapar Polusi Kendaraan di } \\
\text { Kota Cirebon }\end{array}$ & $\begin{array}{lr}\text { Muhammad } & \text { Duddy } \\
\text { Satrianugraha, } & \text { Anisa } \\
\text { Genycea 2016 } & \end{array}$ & $\begin{array}{l}\text { Kadar Timbal (Pb) pada Buah } \\
\text { Jeruk yang Terpapar dengan } \\
\text { yang Tidak Terpapar Polusi } \\
\text { Kendaraan di Kota Cirebon. } \\
\text { Kadar timbal pada kulit jeruk } \\
\text { pre-test yaitu } 0,0901 \mathrm{mg} / \mathrm{kg} \text {, } \\
\text { post-test } A \text { yaitu } 0,1495 \mathrm{mg} / \mathrm{kg} \\
\text { dan post-test } B \text { yaitu } 0,0808 \\
\mathrm{mg} / \mathrm{kg} \text {. sedangkan kadar timbal } \\
\text { pada daging jeruk pre-test yaitu } \\
0,0025 \mathrm{mg} / \mathrm{kg} \text {, post-test } A \text { yaitu } \\
0,0825 \mathrm{mg} / \mathrm{kg} \text { dan post-test } B \\
\text { yaitu } 0,0899 \mathrm{mg} / \mathrm{kg} \text {. }\end{array}$ \\
\hline
\end{tabular}

\section{PEMBAHASAN}

Pada fokus kajian ini membahas tentang hasil penelitian yang telah dilakukan.Dapat diketahui bahwa buahbuahan yang dijual mengandung logam berat timbal $(\mathrm{Pb})$, Buah-buahan aman dikonsumsi jika tidak melebihi nilai ambang batas berdasarkan Peraturan Badan Pengawasan Obat dan Makanan No.5 Tahun 2018 Tentang
Batas Maksimum Cemaran Logam Berat Dalam Pangan Olahan.Standar maksimum cemaran logam berat pada buah adalah 0,20 $\mathrm{mg} / \mathrm{kg}$.

Lidya Novita,dkk (2017), telah melakukan penelitian cemaran logam berat timbal $(\mathrm{Pb})$ pada buah pir yang dijual dipinggir jalan simpang empat lampu merah jalan Soekarno Hatta kota Pekanbaru. Penelitian ini dilakukan dengan survei dan 
Jurnal Sulolipu : Media Komunikasi Sivitas Akademika dan Masyarakat

Vol. 21 No. 12021

e-issn: 2622-6960, p-issn : 0854-624X

analisis dengan SSA (Spektrofotometri Serapan Atom). Pada penelitian ini dilakukan dengan pemajangan dan perlakuan yang bervariasi yaitu pemajangan 0 hari, 6 hari dan 12 hari, serta buah dengan perlakuan tanpa dicuci, dicuci tanpa sabun, dicuci dengan sabun dan dikupas kulitnya.

Pada sampel pemajangan 0 hari tidak di cuci kandungan timbal $(\mathrm{Pb})$ pada buah pir sebesar 2, $1 \mathrm{mg} / \mathrm{kg}$, pada perlakuan buah setelah dicuci tanpasabun sebesar $0,7 \mathrm{mg} / \mathrm{kg}$, dicuci dengan sabun sebesar $0,6 \mathrm{mg} / \mathrm{kg}$ dan dikupas kulitnya yaitu sebesar $0,5 \mathrm{mg} / \mathrm{kg}$. Sampel pemajangan 6 hari pada perlakuan tidak dicuci sebesar $7,9 \mathrm{mg} / \mathrm{kg}$, dicuci tanpa sabun $5,9 \mathrm{mg} / \mathrm{kg}$, dicuci dengan sabun 4,4 $\mathrm{mg} / \mathrm{kg}$, dan dukupas kulitnya sebesar 2,7 $\mathrm{mg} / \mathrm{kg}$. Dan pada sampel pemajangan 12 hari tanpa dicuci $18,5 \mathrm{mg} / \mathrm{kg}$, dicuci tanpa sabun $15,7 \mathrm{mg} / \mathrm{kg}$, dicuci dengan sabun $9,6 \mathrm{mg} / \mathrm{kg}$, dan di kupas ku1itnya $8,7 \mathrm{mg} / \mathrm{kg}$.

Dari hasil tersebut, kandungan logam berat timbal berbeda-beda berdasarkan waktu pajang dan perlakuan pada buah pir. Semakin lama waktu pajang buah maka semakin tinggi kadar timbal pada buah. Dan dengan berdasarkan pada perlakuan pada buah, kadar timbal pada buah mengalami penurunan kadar timbal. Buah dengan perlakuan mencuci dengan sabun cenderung rendah kadar $\mathrm{Pb}$ nya. Dilihat dari hasil tersebut, dimana kadar timbal pada sampel buah pir melebihi nilai ambang batas. Timbal pada buah masuk kedalam tubuh dapat membahayakan kesehatan seseorang seperti gangguan pada fungsi ginjal. Oleh karena itu sangat perlu untuk mencuci buah pir dengan sabun atau mengupas kulitnya terlebih dahulu sebelum mengkonsumsinya.

Vivi Elvira (2011) juga telah melakukan penelitian mengenai Pengaruh waktu pemaparan terhadap kadar timbal dalam buah papaya (Carica papaya.L) yang dijual di beberapa pinggir jalan di Yogyakarta. Sampel buah pepaya pada penelitian ini dititipkan pada 3 pedagan berbeda dan jalan berbeda di Yogyakarta serta waktu pemaparan dalam waktu 4 dan 8 hari.

Hasil penelitian yang telah dilakukan oleh Vivi Elviira di atas. Dari data diatas menunjukkan bahwa terjadi peningkatan kadar timbal pada daging buah papaya seiring dengan lamanya waktu pemajangan. Semakin lama buah papaya dipaparkan maka kadar timbal pada daging buah akan meningkat. Dalam penelitian tersebut kulit buah tidak ikut diperiksa kadar timbalnya, buah papaya dikondisikan sama seperti buah papaya yang akan dikonsumsi. Peningkatan kadar timbal pada daging buah papaya tidak terlalu tinggi karena kulit buah papaya sedikit tebal.

Meskipun kadar timbal pada daging buah pepeya tidak terlalu tinggi daya racun dari bahan pencemar makanan yang bersifat kimia ini ada yang waktu singkat dapat menimbulkan gangguan kesehatan ada juga yang bersifat kumulatif (menumpuk),terutama golongan logam berat dimana setelah beberapa tahun baru menimbulkan gangguan kesehatan umum akibatnya sangat fatal, seperti penyakit kanker, gangguan ginjal, kemandulan dan lain sebagainya (Amaliah,2017)

Musafira, dkk (2015), juga telah melakukan penelitian mengenai kandungan logam berat timbal pada buah apel yang dipajangkan di jalan kota Palu. Sampel buah dipajangakan di 2 jalan kota Palu yaitu di jalan Sisingamangaraja dan di jalan Untada Palu, dengan waktu pemajangan 0 hari (kontrol), 3 hari, 6 hari dan 12 hari. Kandungan timbal pada sampel buah yang dipajangkan di jalan Sisingamangaraja pada buah apel 0 hari (Kontrol) yaitu $0,110 \mathrm{ppm}$, hari ke-3 yaitu $0,168 \mathrm{ppm}$, hari ke-6 yaitu $0,145 \mathrm{ppm}$, hari ke12 yaitu 187 ppm. Pada sampel buah yang dipajangkan di jalan Undata Palu, kadar timbal pada buah hari 0 (kontrol) sebesar $0,077 \mathrm{ppm}$, pada hari ke-3 yaitu 0,162 ppm, hari ke-6 sebesar $0,152 \mathrm{ppm}$ dan pada hari ke-12 sebesar 0,174 ppm. Dari data tersebut dapat dilihat bahwa pada 0 hari buah apel telah memiliki kandungan logam berat timbal. Pada hari ke-3 kadar timbal pada buah meningkat, kemudian pada hari ke-6 mengalami penurunan dan pada hari ke-12 kembali mengalami peningkatan. Hal tersebut disebabkan oleh jumlah kendaraan yang lewat dan faktor cuaca.Jika terjadi hujan maka timbal yang ada di udara ikut jatuh ke tanah sehingga timbal yang masuk ke dalam buah menurun. Dan sebaliknya jika cuaca cerah timbal yang ada di udara tertiup oleh angin mengarah ke arah buah maka kadar timbal pada buah meningkat.

Muhammad Duddy Satrianugraha, Anisa Genycea (2016), melakukan penelitian terkait kandungan timbal pada buah jeruk yang dilakukan di kota Cirebon. Dalam penelitian tersebut sampel buah jeruk diperiksa kandungan timbal pada kulit dan daging buahnya.Jeruk memiliki kulit yang tebal namun kadar logam $\mathrm{Pb}$ tidak hanya 
Jurnal Sulolipu : Media Komunikasi Sivitas Akademika dan Masyarakat

Vol. 21 No. 12021

e-issn: 2622-6960, p-issn : 0854-624X

ditemukan pada kulitnya saja melainkan pada daging buah jeruk juga terdapat kadar logam $\mathrm{Pb}$.

Hasil penelitian yang dilakukan oleh Muhammad Duddy Satrianugraha, Anisa Genycea (2016) menunjukkan kandungan timbal pada kulit dan daging buah jeruk pretest sebesar0,0901 mg/kg dan 0,0025 mg/kg. Serta kandunga timbal pada kulir dan daging buah jeruk post-test A (buah jeruk yang dipaparkan selama 3 hari) yaitu $0,1495 \mathrm{mg} / \mathrm{kg}$ dan $0,0825 \mathrm{mg} / \mathrm{kg}$ dan post-test $\mathrm{B}$ (buah jeruk yang tidak dipaparkan) yaitu $0,0808 \mathrm{mg} / \mathrm{kg}$ dan $0,0899 \mathrm{mg} / \mathrm{kg}$. Sampel penelitian adalah buah jeruk spesies Citrus reticulata yang dijual dipinggir jalan Kalitanjung kota Cirebon.

Peningkatan kadar logam $\mathrm{Pb}$ pada kulit buah jeruk juga dipengaruhi oleh lamanya waktu paparan yang diberikan. Hal ini dikarenakan pada kulit buah jeruk terjadi proses respirasi sehingga logam $\mathrm{Pb}$ yang terdapat di udara dan menempel pada kulit buah jeruk dapat masuk kedalam daging buah jeruk. Faktor lain yang mempengaruhi kadar logam $\mathrm{Pb}$ pada daging buah jeruk yaitu adanya senyawa asam sitrat yang banyak dikandung dalam daging buah jeruk. Asam sitrat merupakan senyawa asam organik yang mampu mengikat ion-ion logam sehingga terbentuk senyawa $\mathrm{Pb}$ sitrat di dalam daging buah jeruk

\section{DAFTAR PUSTAKA}

Adhani, R. Husaini. 2017. Logam berat sekitar manusia. Banjarmasin. Lambung Mangkurat University press.

Amaliah, N. 2017.Penyehatan makanan dan minuman-A.Yogyakarta.Deepublish.

Ashraf,2006dalam Izza Hananingtyas. 2017. Studi Pencemaran Kandungan Logam Berat Timbal $(\mathrm{Pb})$ dan Kadmium (Cd) pada Ikan Tongkol (Euthynnus sp.) di Pantai Utara Jawa. Biotropic. Vol 1. No 2. Agustus $2017: 41-50$

Astawan, M.2008.Sehat dengan hidangan hewani.Jakarta: Penebar Swadaya.

Darmono.2001. Lingkungan Hidup dan Pencemaran hubungan dengan toksikologi senyawa logam. Jakarta. Penerbit Universitas Indonesia.

Elvira Vivi. 2011. Pengaruh waktu pemaparan terhadap kadar timbal dalam buah papaya (carica papaya L) yang dijual di beberapa pinggir jalan di Yogyakarta. Skripsi fakultas farmasi universitas sanata dharma Yogyakarta, online: https://repository.usd.ac.id/17514/ (Diakses pada 22 februari 2020).

Kartikasari, M. 2016. Analisis Logam Timbal (Pb) Pada Buah Apel (Pyrus Malus L.) Dengan Metode Basah Secara Spektrofotometri Serapan Atom.Skripsi. Fakultas Sains Dan Teknologi. Universitas Islam Negeri Maulana Malik Ibrahim Malang. Online:http://etheses.uin-malang.ac.id/3461/1/12630009.pdf (Diakses pada 28 januari 2020). 
Jurnal Sulolipu : Media Komunikasi Sivitas Akademika dan Masyarakat

Vol. 21 No.12021

e-issn: 2622-6960, p-issn : 0854-624X

Kasanah, M, dkk. 2016. Hubungan kadar timbal (Pb) udara dengan timbal (Pb) dalam darah pada pekerja pengecetan industry karoseri di Semarang. Jurnal kesehatan masyarakat.Vol 4. NO 3. Juli 2016 : 825-832. Online: http://www.neliti.com/publications/137511/hubungan-kadar-timbal-pb-udara-dengankadar-timbal-pb-dalam-darah-pada-pekerja-p. (Diakses pada 10 februari 2020).

Ibrahim, K,dkk. 2017. Identifikasi kadar timbal $(\mathrm{Pb})$ pada buah apel (Malus Pumila) yang dijual di pasar tradisional se-kota kendari tahun 2016.Fakultas Kesehatan Masyarakat Universitas Halu Oleo. Jurnal IImiah Mahasiswa Kesehatan Masyarakat. Vol. 2 No.6 Mei 2017 : 250-731.

Muhammad Duddy Satrianugraha, Anisa Genycea. 2016. (Perbandingan Kadar Timbal (Pb) pada Buah Jeruk yang Terpapar dengan yang Tidak Terpapar Polusi Kendaraan di Kota Cirebon). Tunas medika jurnal kedokteran \& kesehatan. vol.3 No.3. 2016 online :http://jurnal.unswagati.ac.id/index.php/tumed/article/view/1725 (Diakses pada 22 februari 2020).

Musafira, dkk. 2015. Analisis Kandungan Timbal Pada Buah Apel (Pyrus Malus.L)Yang Dipajangkan Dipinggir Jalankota Palu Menggunakan Metode Spektrofotometriserapan Atom.Online Jurnal of Natural Science.Vol 4.No.1 2015. $\mathrm{HIm} \quad 32-45 . \quad$ Online :http://jurnal.untad.ac.id/jurnal/index.php/ejurnalfmipa/article/download/3998/2952 (Diakses pada 22 februari 2020).

Novita,L dkk. 2017. Analisis cemaran logam timbal $(P b)$ pada buah pir yang dijual dipinggir jalan simpang empat lampu merah jalan Soekarno Hatta kota Pekanbaru. ljurnal Proteksi Kesehatan. Vol.6 No.2. 2017. HIm 97-103. Online: http://jurnal.pkr.ac.id/index.php/JPK/article/view/73. (Diakses pada 22 februari 2020).

Peraturan Kepala Badan Pengawan Obat dan Makanan Republik Indonesia Tahun 2018. Batas Maksimum Cemaran Logam Berat Dalam Pangan Olahan. Online: https://yuridis.id/peraturan-kepala-bpom-nomor-5-tahun-2018-tentang-batasmaksimum-cemaran-logam-berat-dalam-pangan-olahan/. (Diakses pada 28 januari 2020).

Ruhban,A, Nurwahidah.2017. Tingkat kuantitatif pencemaran logam berat timbal $(\mathrm{Pb})$ dalm udara ambien di terminal malengkeri kota Makassar. Jurnal sulolipu.Vol.17 No.1. 2017. Online: http://journal.poltekkesmks.ac.id/ojs2/index.php/sulolipu/article/view/683/273. (Diakses pada 06 februari 2020)

Sastrawijaya, T. 2009. Pencemaran Lingkungan. Jakarta. Rineka Cipta.

Soemirat,J. 2009. Kesehatan Lingkungan. Yogyakarta.Gadjah Mada University Press.

Sugiyono. 2014. Metode penelitian kuantitatif kulitatif R\&D. Bandung. Alfabeta.

Sunaryo.2007 dalam Reski Amaliah, 2017.Studi kadar timbal (Pb) pada gorengan yang dijual di kota Makassar. Politeknik Kesehatan Makassar Jurusan Kesehatan Lingkungan (KTI tidak dipublikasikan).

Syahadah robiul, 2018.6 Prinsip Hygiene Sanitasi yang Harus Diperhatikan online: https://environment-indonesia.com/6-prinsip-hygiene-sanitasi-yang-harusdiperhatikan/. (Diakses pada 17 juni 2020)

Syamsuddin, dkk, 2019, kesehatan lingkungan teori dan aplikasi.Jakarta. Penerbit buku kedokteran EGC. 
Jurnal Sulolipu : Media Komunikasi Sivitas Akademika dan Masyarakat

Vol. 21 No.12021

e-issn: 2622-6960, p-issn : 0854-624X

Widowati,W. Dkk. 2008. Efek Toksik logam Pencegahan dan Penanggulangan Pencemaran.Yogyakarta. Andi

World Health Organization. 2019. Lead Poisoning and Health. Online:. (Diakses pada 28 januari 2020)

Yerizel,E, dkk.2017. analisis kandungan timbal pada gorengan yang dijual sekitar pasar Tapakis Padang Pariaman secara spektrofotometri serapan atom. Jurnal Kesehatan $\begin{array}{llllll}\text { Andalas. } & \text { Vol. } & 6 & \text { No.3.2017 } & \text { 490-494. Online }\end{array}$ :http://jurnal.fk.unand.ac.id/index.php/jka/article/download/727/583 (Diakses pada 28 januari 2020). 